Brit. F. vener. Dis. (1967), 43, 178.

\title{
GENERAL PARALYSIS OF THE INSANE WITH GUMMA OF SKULL*
}

BY

\author{
S. B. MAHAPATRA \\ Department of Psychiatry, University of Leeds
}

Morbidity arising from syphilitic infection in western countries has progressively declined (Moore, 1951), although there have been reports suggesting that syphilis, especially general paralysis of the insane (GPI), may be increasing again (Steel, 1960; Gooddy, Gautier-Smith, and Dunkley, 1960; Bockner and Coltart, 1961; Brit. med. F., 1965). The recent publications are mostly reports of isolated cases (Nathan and Lawson, 1964; Smith, 1965). The following case presented with GPI and a gummatous lesion of the skull.

\section{Case Report}

A married man aged 56 was transferred to Runwell Hospital in April, 1963, from a neighbouring general hospital where he had been investigated for chest pain with negative findings. His admission to the medical ward followed what his wife described as severe shaking of the body, followed by a period of unconsciousness and, later in the day, crying with chest pain. While undergoing investigation, he threatened suicide and was somewhat truculent.

His wife stated that he had not been himself for 2 weeks, talking a lot, repeating himself, and complaining of tiredness, but he had managed to work until his admission. He had been a life-long asthmatic who was well controlled with isoprenaline spray and had been given intramuscular penicillin on two occasions.

Examination The patient was a right-handed, edentulous, neatly-dressed, pleasant man who looked his age.

CARDIOVASCULAR SYSTEM: Peripheral arteries soft, blood pressure $180 / 90 \mathrm{~mm}$. Hg, carotid pulsations normal, no bruit, no cardiac enlargement, or abnormal pulsations in the chest. Heart sounds normal, localized soft systolic murmur heard over the aortic area.

LUNGS: Normal.

CENTRAL NERVOUS SYSTEM: Argyll Robertson pupils, fine tongue tremor, fundi normal. Reflexes equal but brisk on both sides, normal handwriting, no

* Received for publication March 13, 1967. sensory impairment, Romberg's sign negative. Flexor plantar reflexes.

$\mathrm{He}$ was very talkative, labile in his mood, and grandiose in his attitude. He was correctly orientated but had some difficulty in recalling what led to his admission and made several mistakes when his digit span was tested.

SKULL: No palpable swelling or tenderness.

GENITALIA: No visible scar found. Prostate of normal size and consistency.

On the third day after his admission to Runwell Hospital, he had two major epileptic seizures.

Laboratory Investigations $\mathrm{Hb} 16.4 \mathrm{~g}$. per cent. Erythrocyte sedimentation rate $15 \mathrm{~mm}$. in 1 hour. Normal white cell count. Urine normal. Blood urea $28 \mathrm{mg}$. per cent. Serum alkaline and acid phosphatases within normal limits.

Blood Wassermann reaction and Kahn test* strongly positive.

Cerebrospinal fluid clear and colourless, normal pressure, 14 cells/c.mm (all. mononuclears). Protein 70 mg. per cent. Wassermann reaction and Kahn test strongly positive. Lange curve 5554320000 .

Skull $x$ ray showed osteoporotic defects between tables in the occipital region (Fig. 1, opposite).

Chest $x$ ray normal.

Electrocardiogram physiological.

Electroencephalogram (on the day after admission) showed irregular post-central activity with traces of alpha rhythm at 8-10 c/s and the presence of fairly regular moderate voltage slow activity (much in the delta range) in the temporal region. These abnormalities were possibly the result of a fit he had at home.

PSYCHOMETRY: I.Q. 121 and memory quotient 126; he showed difficulty in abstracting on non-verbal material but there was no evidence of intellectual impairment.

Treatment and Progress In the first week he was given phenobarbitone sodium $30 \mathrm{mg}$. three times a day, and on the tenth day, after a test dose of penicillin, he was given a fortnight's course of intramuscular procaine penicillin 800,000 units/day without untoward reactions.

\footnotetext{
* The wife's reactions were negative.
} 
FIG. 1.-Skull $x$ ray (April, 1963), showing osteoporotic defects (arrow).

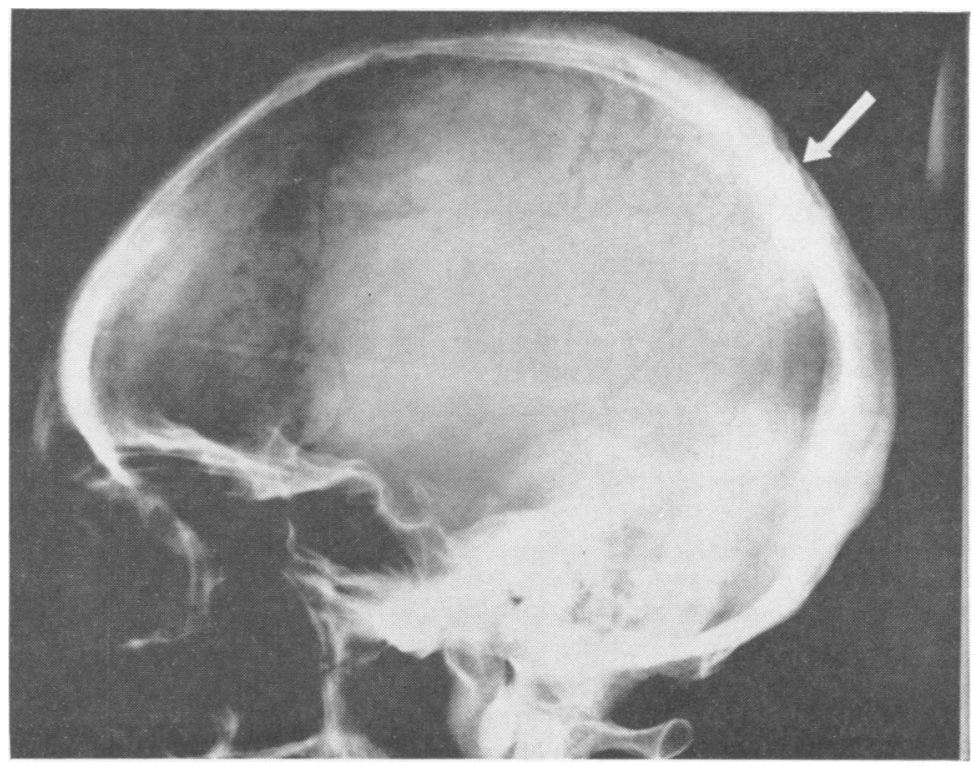

He left hospital at the end of 4 weeks and a fortnight after his discharge went back to his old job and apparently coped well. He had no further fits and the phenobarbitone was discontinued 3 months after his discharge.

Follow-up In July, 1965, he was found to be grandiose, garrulous, and circumstantial, but there were no other changes in his physical or intellectual state.
Erythrocyte sedimentation rate $8 \mathrm{~mm} / \mathrm{hr}$. Blood Wassermann reaction and Kahn test strongly positive.

Cerebrospinal fluid 2 cells $/ \mathrm{cmm}$., protein $65 \mathrm{mg}$. per cent. Wassermann reaction and Kahn test positive with paretic Lange curve.

Skull $x$ ray showed evidence of recalcification of the osteoporotic defects (Fig. 2).

Chest $x$ ray and electrocardiogram normal.

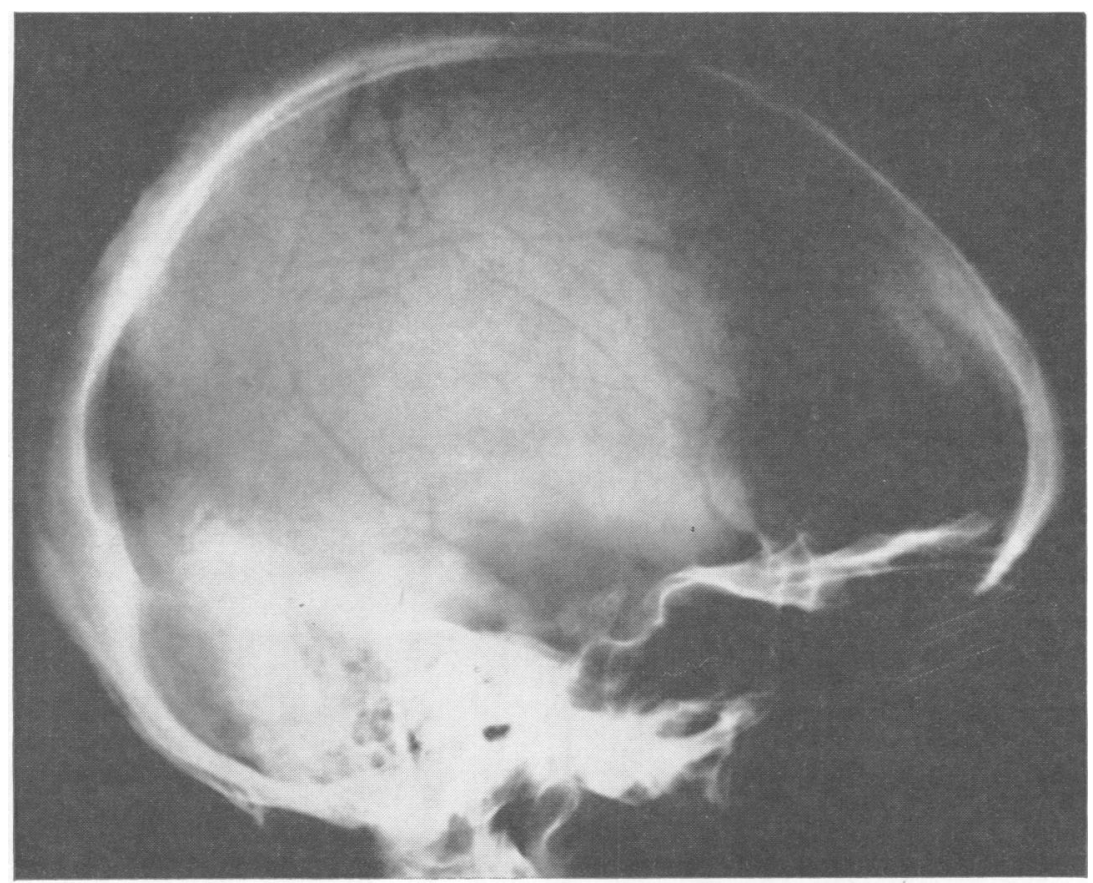

FIG. 2.-Skull $x$ ray (July, 1965), showing evidence of recalcification. 
Electroencephalogram showed return of more regular alpha rhythm.

Psychometry: No impairment in cognitive sphere.

\section{Discussion}

Two manifestations of tertiary syphilis were present in this case, i.e. general paralysis and a gumma of the skull, the latter being found only on $x$ ray. The striking psychiatric feature was the presence of grandiosity without obvious intellectual deterioration. Early diagnosis was made possible by the major epileptic seizures, although seizures are reported to occur very rarely in the pure grandiose types of general paralysis of the insane, though they are common in pure dementing types (Nicol and Hutton, 1935). The bony lesion consisted of rounded areas of osteoporosis between the tables of the vault of the skull with no local swelling or tenderness. This is compatible with the presence of a central gumma (Thoma and Goldman, 1960). Syphilitic lesions of bone have become rare although there have been case reports describing involvement of the mandible (Nathan and Lawson, 1964) and palate (Smith, 1965). It was difficult to explain the chest pain which first led to this patient's admission to hospital, but uncomplicated syphilitic aortitis was suspected in view of the presence of the aortic systolic murmur. Moore, Danglade and Reisinger (1932) have pointed out the difficulty of diagnosing such conditions on purely clinical grounds.

Since treatment with penicillin, his intellectual status has not deteriorated, he has had no more fits, and the cerebrospinal fluid cell count has dropped to 2 cells/cmm. The Wassermann reaction and Kahn tests of blood and cerebrospinal fluid have remained positive with the Lange curve paretic (c.f. Steel, 1960: Case 14).

Two years later the gummatous lesion, though partially recalcified, was by no means completely healed (King and Nicol, 1964), and the grandiosity and pressure of speech have remained unaltered in spite of treatment. The satisfactory outcome in the present case was the result of early diagnosis and treatment. The absence of penicillin resistance (Birkett, 1961) or toxic reactions, his stable intelligent premorbid personality, and his early return to work no doubt contributed to his recovery (Whelen and Bree, 1954).

It is beyond the scope of this paper to ascertain whether syphilis is on the decline (Moore, 1951, 1956; King, 1958) or is rising again (Brit. med. F., 1965). Laird (1962) failed to find any rise in the incidence of general paralysis of the insane in his survey of the hospitals in the Manchester region in spite of the reports of Steel (1960) and Bockner and Coltart (1961).

\section{Summary}

A case is described of general paralysis of the insane with a gummatous lesion of the skull confirmed by $x$-ray examination. Early diagnosis and well-tolerated treatment with penicillin led to a satisfactory outcome and the patient was able to return to work with only slight residual personality and affective changes.

Sporadic cases of tertiary syphilis do occur with no history of earlier manifestation of the disease. This may be due to the widespread use of penicillin and other antibiotics in non-syphilitic infections so that the primary symptoms are suppressed.

I wish to thank Dr G. D. Fraser Steele, physician superintendent, Runwell Hospital, for permission to publish this case, and Dr R. Strömolsen and Dr I. A. Cameron under whose care the patient was admitted.

\section{REFERENCES}

Birkett, D. A. (1961). Brit. F. vener. Dis., 37, 202.

Bockner, S., and Coltart, N. (1961). Brit. med.F., $1,18$. Brit. med. F. (1965). Leader, 2, 433.

Gooddy, W., Gautier-Smith, P. C., and Dunkley, E. W. (1960). Lancet, 2, 1290.

King, A. (1958). Ibid., 1, 651.

and Nicol, C. (1964). "Venereal Diseases". Cassell, London.

Laird, S. M. (1962). Brit. med. F., 1, 524.

Moore, J. E. (1951). Lancet., 1, 699.

- (1956). Brit. F. vener. Dis., 32, 217.

-, Danglade, J. H., and Reisinger, J. C. (1932). Arch. intern. Med., 49, 753.

Nathan, A. S., and Lawson, W. (1964). Oral Surg., 17, 284.

Nicol, W. D., and Hutton, E. L. (1935). F. ment. Sci., 81, 804.

Smith, R. M. (1965). Oral Surg., 20, 29.

Steel, R. (1960). Lancet, 1, 121.

Thoma, K. H., and Goldman, H. M. (1960). "Oral Pathology", 5th ed., p. 728. Mosby, St. Louis.

Whelen, M., and Bree, M. H. (1954). Lancet, 1, 70.

\section{La paralysie générale accompagnée d'une gomme du crâne RÉsumé}

Un cas de paralysie générale accompagné d'une gomme du crâne confirmée par les rayons $X$ est décrit. Le diagnostic fait dès le début et le traitement bien toléré avec de la pénicilline ont donné un résultat satisfaisant, et le patient a pu retourner au travail avec très peu de changements résiduels à peine marqués de sa personnalité.

Les cas sporadiques de syphilis tertiaire ont lieu sans aucun historique des manifestations antérieures de la maladie. Cela est peut-être dû à l'usage généralisé de la pénicilline et d'autres antibiotiques dans les infections non-spécifiques de sorte que les symptômes primaires sont supprimés. 